\title{
Conflict resolution in Nigerian partisan politics: Insights from the quest for leadership in Markan narratives
}

\author{
Honor Maupego Sewapo* and Enock Oluwadare Ajibade \\ Department of Religious Studies, Faculty of Arts, University of Nigeria, Ibadan, Nigeria. \\ *Corresponding author. Email: honorsewapo@gmail.com; Tel: +234 8034233298.
}

Copyright (@ 2021 Sewapo and Ajibade. This article remains permanently open access under the terms of the Creative Commons Attribution License 4.0, which permits unrestricted use, distribution, and reproduction in any medium, provided the original work is properly cited.

Accepted 22nd December, 2020; Accepted 7th May, 2021

\begin{abstract}
The quest for leadership, request to secure the foremost seats of influence at the side of Jesus (as done by James and John), is evident within Markan narratives. After this indecorous request, conflict crept into the camp of Jesus' twelve disciples as the ten other disciples fumed over James' and John's bid to outflank them in prominence. Extant literature has focused on the event surrounding their request and the quality of the greatest in God's service to the neglect of Jesus' strategy of resolving the conflict, its contribution to the success of Jesus' ministry and its relevance to resolving conflict in contemporary partisan politics. This paper, therefore, examines the quest for leadership in Markan narratives (9:33-37 and 10:35-45), with particular reference to Jesus' strategy of resolving conflict. This is with a view to establishing its relevance to resolving Nigeria's partisan political conflict. Fuchs' theory of the New Hermeneutic was adopted. Data were subjected to exegetical analysis. Findings will have implication on conflict prevention and/or conflict resolution in human endeavours.
\end{abstract}

Keywords: Conflict, James, John, leadership, Mark's gospel, Nigeria, partisan politics, political parties, quest.

\section{INTRODUCTION}

The quest (for leadership) by James and John to secure the foremost places of authority and have prominent seats at both sides of Jesus in Markan narratives is similar to the quest for leadership among Nigerian politicians in a number of ways. This overbearing quest for leadership at every stratum of human society has bred several untold conflicts either at sacred or secular institutions. At every segment of the society, be it sacred as in ordination, church society, theological seminaries and episcopacy or secular such as in politics, communities, social gatherings, families and kinsmen, campuses, government ministries, departments, agencies, parastatals and institutions at local, state and federal, there have been cases of unhealthy rivalry, leading to one form of conflict or the other. Mark 10:35-45 is chiefly divided into two major parts: the sons of Zebedee's selfish request which provokes conflict in Mark 10:35-40 and the responses of Jesus to their selfish response which is a panacea to leadership conflict in Mark 10:38-45. Jesus' responses to the duo in
Mark 10:38, 45 are very instructive. The responses emphasise new understanding and status reversal that gives a new orientation and correct meaning to leadership. Fuchs (1971)'s theory is apposite here as he posits that the job of exegetes these days is to reconstruct that familiar world of understanding which is the essential foundation of effectual communication of speech and appropriation of its fact. The manuscript does not merely serve to transmit kerygmatic formulation, but instead a pointer that leads us into the language milieu of our way of life.

\section{LEADERSHIP: TOWARDS A CONTEXTUAL UNDERSTANDING}

Agbude (2018) says that the word "leadership" in our contemporary world as at the year 2015 had over $600,000,000$ references on Google search alone. The 
Integ. J. Arts and Human.

word "leader" had over $880,000,000$ references, "leadership development" produced 2,876,000 references, while Amazon.com had 173,522 books on "leadership". As at 5th July 2018, the word "leadership" had over 2 billion references. This implies that leadership has several concepts and definitions within different people and contexts. This also alludes to the fact that the concept of leadership is one of the most researched and talked about in all human endeavours. Definitions of leadership are usually in line with the description of concept within the area under discussion from law to medicine, engineering to social sciences, management science to arts and humanities and from secular to sacred/religion/tradition.

Lewin et al. (1939) opine that the understanding of leadership style is primarily dependent on the ability to distinguish among autocratic, democratic, and laissezfaire leaders. Despite frequent citation of this leadership model, House and Mitchell (1974) recommend a later model which addresses some specific communicative elements of each leadership, such as directive, participative, supportive and achievement-oriented leaders. These definitions are more or less a servantleadership inclined which is centred on services to others (Wilkes 1998:18). Mark 10:35-45 is preferred to Matthew 20:20-28 because priority theory affirmed that Quelle and Logo are the main sources of Mark, while Matthew drew from the three and that the first name Salome, Mother of James and John, who was at the same time the sister of Mary, the mother of Jesus was not in Mark. Matthew's colouration was that she was the one that brought her two sons, while Mark said that they came by themselves (Metzger, 1994). Hargreaves (1995) sees this text as a collection of teachings and training that Jesus gave to his disciples concerning the "servant" Messiah and His "servant" followers which he expects to be very instructive to them. Jesus here noted with dismay that these disciples are yet to grasp his new scale of values as James and John display a remarkable lack of awareness of what Jesus has been teaching them about leadership and servanthood.

Jesus had told them his mission on earth, he had appeared to present his life a payment for countless souls, but when he viewed the personal ambitions of James and John, it was still not in agreement with what his response was to them in Mark 9:33-35. France (2002) avers that "He sat down and called the twelve"; this is an intentional act of Jesus to attend to this fragile question of "who is the greatest?" or "who is going to be the leader among us?" Jesus provided to them the rules for prominence. "If any

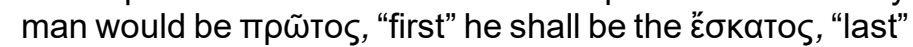
of all and ठı⿱㇒́xovos, "minster" of all". For Robertson (2018), this approach to quest for leadership is what Jesus gave, like many other instructions that are repeated at other synoptic gospels such as Mark 10:43, Matthew 23:8, and Luke 22:24. In all these texts, the disciples argued who would be the greatest or who would be the leader. But here in Mark 10:35 the issue of status is again raised among the disciples about "which of them should be the greatest". With this supposition that Jesus was on the path to "glory" and James and John presented their requests was amazing after most gloomy and comprehensive of Jesus passion prophecies (Hargreaves 1995:186). In Nigeria's partisan politics, there are constant quests for position by people even to the detriment of others in the same family, party, senatorial district, constituency, local government and wards. Even people who are not eligible will stubbornly want to vie for elective positions.

According to Sewakpo (2015), the colonial and postcolonial eras in the country have recorded quite a number of individuals who have provided leadership for national aspirations. In this regard, mention can be made of Herbert Marcauly, Nnamdi Azikwe, Tafawa Balewa, Obafemi Awolowo and Ahmadu Bello who had led relatively better in policy making for national wellbeing, infrastructural development, health, education, power and so many other critical institutions than the crop of leaders that we have now. The contemporary Nigeria has experienced so many conflicts that thereafter degenerated into arson, murder, politically motivated assassinations, abductions, vandalism, legal tussle and several other barbaric acts that had thrown communities, families and individuals to mourning and great losses just because somebody wanted a position by all means. Kinsmen are not left out, father and son/daughter do clash because of partisan politics. In addition, the practice of partisan politics and its activities have been causing bad blood in Nigeria.

\section{LITERATURE REVIEW}

Henry (1961) sees Mark 10:35-45 as a check that Jesus gave to two of his disciples. Their ambitious request was said to have been made by their mother, Salome. However, Markan account affirms that the two young men made the request by themselves; and this research aligns with Markan priority. Henry condemns this boundless request as it goes against the Lord's Prayer as taught by Jesus Christ, "we want that you do for us whatsoever we shall desire". Henry, therefore, opines that man should better leave his request open-ended to Christ as he would do for him what sees fit and he will do more than we desire (Ephesians 3:20). This is a laudable work from Henry. The context of Mark 10:35-45 as opined by David and Alexander (1952) is all concerned with Jesus reiterating the predictions of his death and how the disciples bicker over the would-be future status in Jesus' glory. Bruce (1986) captions Mark 10:35-45 as the demand of James and John. This appeal of James and John to sit at either side of Jesus in His Glory, that is, the Messianic Kingdom that he was about to set up, as they envisaged this, was not outright granted to them. It is interesting to note that Jesus did not only refuse to grant them their request, but 
made them to understand that the matter in question did not come within the scope of his jurisdiction. Jesus there and then gave them conditions upon which their request may be granted in part, on the willingness of His followers to suffer for His sake and such suffering he described metaphorically as drinking from His cup and being baptised with His Baptism which are both suggestive of suffering to the point of death. Though this piece is comprehensive, but does not deal with the issue of partisan politics in the Nigerian experience.

Hargreaves (1995) avers that colourations of Mark 10:35 are so crude and rude: "We want you to do for us whatever we ask of you". The request by James and John is exactly opposite to the sort of prayer which Jesus had taught them to pray. Their request can also be recast as "Do for us what we have decided is best for us", while the Christian prayer is, "Your will be done", that is, "We are willing to do whatever you want us to do". The intention of James and John was selfish. They wanted to hold more important posts and positions than the other disciples when Jesus would become king in Jerusalem. Luke 19:11 shows that they still expected that Mark 10:37 refers to the Kingdom of God that was to appear immediately; and it shows the blindness of the disciples yet. This work is indeed relevant but it focuses more on the spiritual milieu of the clergy than the laity.

The selected biblical passage, Mark 10:35-45, plays a key role in understanding the purpose of Jesus' death and its significance. In the preceding scene in Mark 10:32-34, Jesus gave his concluding and ever thorough prophecy of his closing test, anguish, death and resurrection. Jesus was about entering Jerusalem and to brazen out with the temple-based nobility; James and John are requesting privileged places of authority at Jesus' right and left sides. By doing this, the author condemns the two sons of Zebedee for missing everything that Jesus had said and done since Mark 8:27. They recognised that adoration is waiting for Jesus. The power that he has demonstrated in his ministry will show the way to a great glory, and possibly to an imperial rule, and the duo conspired to capitalise on that.

This passage is summarised within the context of tyrant, servant and freedom discourse (Malbon 2006:271-297), which is very different from the purpose of the research that seeks to bring panacea to the conflict that ensues from leadership quest among the political class in Nigeria. James and John were brothers; they asked Jesus for a big favour. They wanted the premium seats. They also wanted prestige and power. The other ten disciples were not better than the twelve because they too became very angry; they fumed and goofed because they too wanted the premium seats. They missed the kingship context of Jesus.

\footnotetext{
${ }^{1}$ All the biblical quotations in Greek Language as contained on the article are taken from Aland, B., Aland, K., Karavidopoulos, J., Martini,
}

\section{EXEGESIS OF MARKAN NARRATIVES}

An attempt is made to exegete Mark 10:35, $37-45$ and the application of this will serve as a panacea for conflict in Nigerian partisan politics. There are two major causes of conflicts as seen in Mark 10:35 and 37 about the indecorous requests of the sons of Zebedee and Salome. For instance, Mark gives the narrative of their first request as follows: moıńons nं ĩv $^{1}$, "Teacher, we want you to do for us whatever we ask of you" (Mark 10:35b).

As Jesus progressed in his journey to Jerusalem, the two disciples flashed back on what Jesus had told them previously in Matthew 19:28, "Truly I say unto you (disciples) in the new world, when the son of man shall sit on his glorious throne, you who have followed me will also sit on twelve thrones, judging the twelve tribes of Israel" (Wiersbe 1989). Probably, this was what informed the siblings to make such a prestigious request. Several scholars have called their request different names: Exell (1849) explicates it as "unwholesome competition", while Hoffacker (2010) claims that it craves for "premium seat, prestige and power". In addition, Exell (1849) opines that such a request suggests a "collision with God", kinship misconception, self-interest and ambition-misconception.

This shows the selfishness of man across board. As Weitnauer (2015) rightly puts it, the disciples are all out for self-interest but Jesus was all out for selfless service and that whenever man comes to God it is always "gimmie gimmie gimmie" of whatever we ask of you like a baby. This verse addresses the two brothers' desire for power. James and John are not the only followers that are attracted by the mental picture of glorious reign because the remaining twelve disciples got enraged over their proposal to outshine them in reputation. This is a major source of conflict. The request of the two brothers was outrageous. As a corollary to the above submission, Mark presents the narrative of their second request as follows:

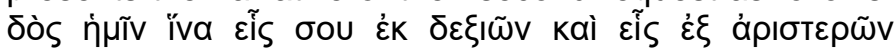

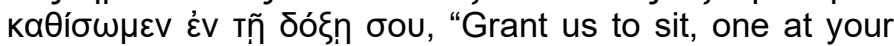
right hand and one at your left, in your glory" (Mark 10:37).

The account of Mark 10:35 suggests that "James and John came unto Jesus - they did this through the instrumentality of their mother". They did not come "personally", but got their mother to put together their request for them if compared with Matthew 20:20. In either way, both young men were culpable because one can imagine the kind of heated arguments that sprang up among them as they marched behind Jesus, and how they felt ashamed when "He called them".

The reason that this indecorous request was so selfish is that, these two brothers were seeking for an impressive Jewish kingdom with futuristic characteristics in the

C. M., \& Metzger, B. M. (2007). The Greek New Testament - Fourth Revised Edition - Dictionary: D-Stuttgart: Deutsche Bibelgesellschaft. 
Integ. J. Arts and Human.

apocalyptic end of the Messianic kingdom. This request of theirs brushed aside all that Jesus had talked about in his death and resurrection as sheer distrust. As Jesus went up the mountain to entreat with his Father, James and John were standing by (Mark 9:2-8). They witnessed the events that took place there; they listened to the voice of God. So, James and John had no doubt like Peter. Mark 8:29 affirms that Jesus was the anointed to come. So, they perceived that Jesus would definitely be the apocalyptic king and they too would certainly rule on God's behalf.

Mark 10:38-45 x-rays Jesus' dossier for conflict prevention at every stratum in these ways; the first in the

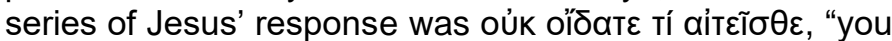
know not what you are asking" (Mark 10:38a)". This is very instructive to curb excessive request that can breed conflict. In Mark 10:38a, Jesus opened up these gogetting, ostensibly cutthroat siblings; you have little knowledge concerning what you are requesting for. God habitually responds to our prayers in any of these four traditions. "Yes," "no," "wait," or "you do not know what you are asking". Jesus' response to their command and demand is "You do not know what you are asking." A good number of humans' prayers usually tell Jesus what to do and not what he would like to do for us (Kraybill 2018: 137138).

Nevertheless, it is important to be reminded that Jesus did not reprimand them. He was pleased that they desired the kingdom and took time to explain to them that biblical dream needed to be changed into meekness that was geared towards helping others. He wanted James and John to "climb down the ladder to greatness". So, Jesus cautioned them about what their desire would entail in their quest for the kingdom's prominence. He categorically announced to them that greatness, preeminence, power and primacy would involve suffering.

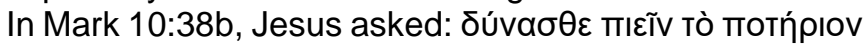

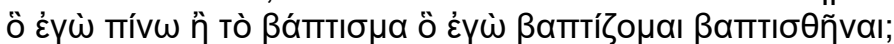
"Are you able to drink the cup that I drink, or to be baptised with the baptism with which I am baptised?" The concepts of mív $\omega$, "wine" as contained in (Psalm 75:8; Isaiah 51:17; Ezekiel 23:31-34; Habakkuk 2:16; Zechariah 12:2) and

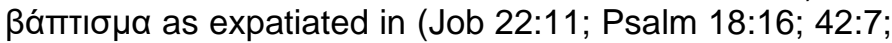
69:1-2, 15; Isaiah 43:2) are very instructive; both the similarity of the cup and baptism were employed symbolically in the prehistoric world for affliction. Jesus was enquiring from these young men, if they were able to endure similar type of agony that he is getting ready to enter into and their answer was ठuvá $\mu \varepsilon \theta \alpha$, "we are able and/or we are powerful" (Mark 10:39a). However, Jesus wanted them to focus on their present engagement instead of future glory. These brothers thought that they were able to bear all the sufferings that Jesus was expecting them to pass through. The reason was that they had not fully comprehended what He had predicted. They were instead thinking of military and political reputation and consequently, they were confident.
However, Jesus continued in his comprehensive answers to their request which is another panacea to conflict by telling them that even when you are well prepared to suffer with him, the seats on my right and left are á $\lambda \lambda$ 'oís пंтоі́ абтаı, "but it is for those for whom it has been prepared" (Mark 10:40b). The Greek iंтoífaotal is

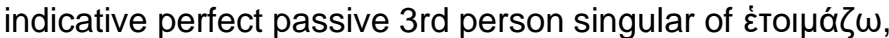
denoting "put or keep in readiness, prepare". Thus, the

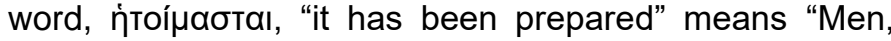
keep serving me, prepare to suffer for me, and my Father will determine your status in the kingdom; do not allow impure desire to tarnish your request for greatness, because a man's character is shown by the things that provoke his strongest reactions" (Cole 1989:170).

Another great panacea to conflict as suggested by Jesus

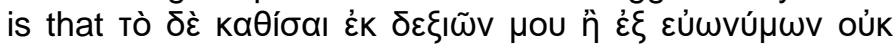

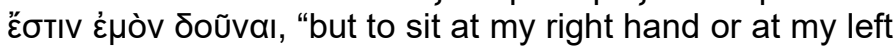
is not mine to grant" (Mark 10:40a). Jesus is of the opinion that "however partial he may be to these two brethren, seats in glory can only be given to those who are fit for them". For Clarke (2005), favour cannot prevail here. This means that the elevated seats are for those filled with virtues and fullness of God not only to those who ordinarily covet it. Though after a long period just according to the predictions of Jesus to the two brothers, they did partake

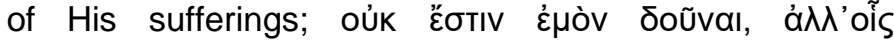
ทंтоі́ абтаı, "is not mine to grant, but it is for those for whom it has been prepared" (Mark 10:40b). The emphasis here, according to Wallace (1997), is on "Not mine to give", what a wonderful tranquilizer to position cravers, "it is not mine to give", is a complete phrase that is followed by the separate statement; "but is reserved for those for whom it is prepared" which means if it is not meant for you in God's prerogative, it can never be given to you, no matter how much you dream about it.

Jesus' great teaching about leadership came to the limelight here again. Before the indecorous request/ command of the two sons of Zebedee escalates to a noisy fight, He gathered his followers and said to them, "You know that those who are supposed to rule over the Gentiles lord it over them and their great men exercise authority over them. But it shall not be so among you; but whoever would be great among you must be servant and whosoever must be first among you must be slave of all" (Mark 10:42-44).

In these three verses, Jesus was trying to teach his disciples the concept of "the upside down kingdom". Three observations identified here are as follows:

- Jesus employs the word "you" four times. His objective is to differentiate the humankind of leadership with God's leadership code. Jesus portrays the manner that the world's kind of leadership functions in Mark $10: 42$ and then compares God's sovereignty with the world's method in Mark 10:43-44. The world claims admiration through arrogance, supremacy and force. 
But the disciples of Jesus should be humble and bring to bear humility, refinement and service. In the secular leadership system, the higher you go, the more you are served (Scroggie 1980:189).

- Jesus uses a subjunctive mood $\theta \varepsilon \dot{\lambda} \lambda \eta$ which indicates "would or wish" that some of them would want to be preeminent or foremost. The expression is also in the present tense indicating a continuous process or aspiration.

- Jesus differentiates among סiókovos, "servant" and

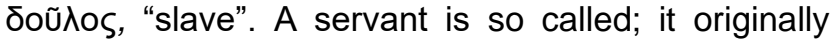
means "to heap dust, because a good servant moved so fast that dust flew around him". Also, it was employed for boys who are in charge of carrying towels in the bath houses. In the religious parlance, servant is anybody who ministered or provided a service to someone else. The slave, conversely, is anyone who does not have the audacity to decline any duty. The slave's whole life is at the mercy of his owner. Jesus wants his disciples and whoever wants to be a leader to always climb down the ladder to greatness (Garland 2002:265).

The latter part of this text emphasises more about status reversal. This exegesis concludes with some shocking notes; the New Testament portrays Jesus as, "the Son of man has not come to be attended to, but to attend to others, and to grant His life a payoff for many". It is

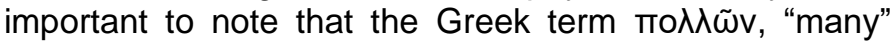
literarily contrasts with uuxìv, "the one life" of Jesus given as a payment (Mark 10:45 cf. 14:24). Just one man's singular act affects several others. "Many" does not connote some in distinction from all. On the one hand, Jesus' death profits everyone; and on the other hand, His death profits the elect. That was not to point to Jesus' contrast here, but that Jesus substituted himself for everyone else by forfeiting the sentence for their sins. In this sense, Jesus is the grand model of it all. The method of going up is down. This verse should not only be seen as the high point of Mark10:35-45, but it is the crux of Mark's Gospel.

\section{LEADERSHIP IN NIGERIAN PARTISAN POLITICS}

Having examined the quest for leadership in Markan narratives and how it bred conflict among the disciples in the selected biblical passage, Mark 10:35-45, this section shall discuss Jesus' strategy of resolving the conflict with a view to proposing a conflict resolution strategy in contemporary partisan politics in Nigeria.

Leadership and religion globally are almost inseparable because human's theology determines his anthropology, and his anthropology dictates what his sociology would be. Jesus Christ in these Markan narratives has given a dossier for conflict prevention and resolution as would be highlighted below.

Impaired knowledge about what leadership actually entails as corrected by Jesus is prophylactic to Nigerian partisan politics. Man believes that politics or leadership is to overpower and tyrannise. Jesus took time to correct their mental picture by holding up the principles of heathen's socio-political system as unconstructive examples. The Gentiles rely on coercion and control to maintain their dominance and prerogative. Self-interest and self-protection are also to be done away with as Jesus has counselled on leadership.

From Jesus' new orientation about leadership, it could be inferred that the real understanding of leadership is very synonymous to suffering (Malbon 2006), losing one's right, forfeiting what legally belongs to one and getting oneself involved in a selfless service (Garland 1996: 416). If all these are put in the right perspective, partisan politics in contemporary Nigeria would not be fight-to-finish and/or a do-or-die affair, since whoever is going there would know that he is going to serve his generation selflessly. Partisan politics would be devoid of unhealthy competition, killing and maiming; this was probable of Jesus' new orientation. People who play partisan politics in Nigeria will not be overambitious if they know as Jesus taught that it is God alone who is in charge of the final verdict about who occupies what position/post. Human beings pursue political positions in the Nigerian political circle as if all power to become whatever lies in their hands.

In the Nigerian experience of partisan politics, politicians like Shehu Musa Yar'adua, Chief Obafemi Awolowo, Chief Olu Falae, Chief M. K. O. Abiola, Bashir Tofa and Abubakar Atiku worked and campaigned throughout the length and breadth of Nigeria but could not become the President of the country because it was not the will of God for them. If they had known that all power, leadership, headship and prestigious seats/positions belong to God, they would have not suffered colossal loss in finance, time, energy and materials in their bid to become president. Conversely, people like Chief Olusegun Obasanjo, Chief Ernest Shonekan, Sheu Umaru Yar'adua, Dr Goodluck Jonathan and Gen. Muhammadu Buhari (rtd) got their own presidency without much struggle because God has designed it to be so.

James' and John's quests for leadership have a parallel in Nigeria's political space with the likes of Dr. Olushola Saraki and his step-sister Gbemisola Saraki who are siblings, but are vying for the governorship seat in their state (Kwara State of Nigeria) at the same time though on the platforms of different political parties as if God had assured the duo that they would both make it to the seat. If God factor and His primacy are conscientiously considered, much political friction will be completely avoided in the partisan politics of Nigeria.

In the quest for leadership in the Nigerian political space, if all intending aspirants are fully aware of Jesus' teaching that whoever would be first/great/lead should be a servant, 
Integ. J. Arts and Human.

the much political conflict witnessed in the country would/ could have been averted. The principles of servant leadership are very far away from our political experience in the Nigerian partisan politics. As some had advocated that Nigeria's legislature should be a part-time job and to be more or less a volunteer service both at the state assemblies and the upper and lower chambers of the national assemblies, then it will be less competitive and a true leader would always emerge to lead and legislate for the populace.

Also, if the professional medical doctors such as Dr. Chris Ngige, Dr. Bukola Saraki, Dr. Olusegun Mimiko and the professional lawyers like Yakubu Dogara, Femi Gbajabiamila and Yemi Osinbajo who have ventured into politics are fully aware that they would be servants per se, assuredly they might not have probably taken to politics because servanthood is disgusting, insulting, derogatory and dirty. But they all know that it is prestigious, a premium seat and a position of lordship, men would dare anything to get there.

In biblical leadership, according to Markan narratives, Jesus' response as a panacea to leadership conflict is very instructive. It emphasises a new understanding and status reversal that gives a new orientation to servant leadership. The world leaders' demands are respect through pride, power and prestige, but servant-leadership should be unassuming, should demonstrate humility, and should reveal grace and life dedicated to serve God and humanity (Evans 1999: 314). In the world as well, the higher you go the extra you are served by your subordinates. But the concept of drinking the cup and submitting to his baptism is not in congruity with the world's system of lording it over their subjects.

\section{PROPOSED SOLUTION TO LEADERSHIP CONFLICT IN NIGERIAN PARTISAN POLITICS}

Proper tutelage should be advanced for as many that want to assume leadership position so that they would know all it entails to ascend leadership position. If they know that it is demanding and it is a herculean task to administer humans, money and materials resources, only humans with the heart of service will present themselves for leadership positions.

Markan narratives posit that leadership is synonymous to suffering and not enrichment, personal aggrandisement and laundering national resources to foreign banks. But a life of real selfless service will deny whoever is leading a life of amassing wealth recklessly.

The primacy of God in human quest for leadership should be stressed to Nigerian partisan politicians. God is the ruler over the kingdom of men and $\mathrm{He}$ is the only one who can either promote someone to an enviable position or relegate the other. The issue of "do for us whatever we desire" and at all cost must be done away with as a panacea to leadership conflict either at sacred or secular institutions. Do for us whatever we desire will lead to unethical conducts.

\section{CONCLUSION}

The quest for leadership at every stratum of human society has bred several untold hardships, conflicts and acrimony among people and kinsmen as indicated in Markan narratives. The causes of conflicts as vividly seen in Mark 10:35 and 38 are inordinate desires, shallow knowledge about what leadership is and empty boast $\delta u v a ́ \mu \varepsilon \theta \alpha$, "we are able" that they can do one thing or the other, selfishness and propensity to outshine one another. Jesus in this Markan narratives gave strategies to prevent and resolve whatever conflict that can ensue through leadership quest to include status reversals of climbing down the ladder to greatness, the upside down leadership style and selfless service principles and suffering. On top of it all, humans should know that the prerogative to lead either at sacred or secular circles belongs exclusively to God. He is the one who can elevate or demote. The mindset of "do for us whatever we desire" was also denounced by Jesus as a panacea to indecorous request or command.

Among the partisan politicians in the Nigerian political space, Mark 10:35-45 is advocated to be the template for them in the areas of knowing what leadership is really about as the administration of humans, money and materials selflessly with integrity and that political leadership is not to lord it over the masses, but to be responsible to them in all spheres. This paper brings to bear how correct and sincere mindset is a good foundation for quest for leadership and that vote buying, use of threats, advanced electronic rigging method, compelling returning officers to announce loser's name under duress, the use of force by police or military to disenfranchise or cause voters apathy are all factors that cause conflict on the path to leadership.

There is no gainsaying that religion has played a significant role in leadership conflict and resolution. Strategies to prevent and resolve whatever conflicts that ensue through leadership, especially in the Nigerian partisan politics can be resolved using Christ-like's approach. Markan narratives, therefore, advocate all would-be partisan politicians in Nigeria to toe the cautionary path of Jesus Christ's model of leadership as enshrined in Mark's Gospel, Mark 10:35-45, in order to jettison anything that can cause conflict and disagreement. Then partisan political leadership in Nigeria will be enviable, honourable and accountable; laced with selfless service that is channeled towards the wellbeing, peace, development and stability of all the citizens. 


\section{REFERENCES}

Agbude, G. A. (2018). Leadership without tears. Charis Leadership Library Series. London: Scepter

Alexander, P., \& Alexander D. (1992). The Lion Handbook to the Bible. Oxford: Lion Publishing.

Barbieri, L. (1995). Mark. Moody Gospel Commentary. Chicago: Moody.

Bruce, F. F. (1986). The International Bible Commentary. Grand Rapids: Zondervan Publishing House.

Cole, R. A. (1989). The Gospel According to Mark. Tyndale New Testament Commentary. Leicester: Tyndale New Testament Commentary

Evans, T. (1999). Who is This King of Glory? Chicago: Moody.

Exell, J. S. (1849). The Biblical Illustrator. The Gospel According to Mark. Grand Rapids, Michigan: Baker Book House.

France, R. T. (2002). The Gospel of Mark: A Commentary on Greek Text. Grand Rapids: Wm. B. Eerdmans Publishing Company.

Fuchs, E. (1971). The Hermeneutical Problem. In. Robinson J. M. (ed.). The future of our religious past: Essays in honour of Rudolf Bultmann. London: SCM Press. Pp. 276-278.

Garland, D. (1996). Mark. NIV Application Commentary, New Testament. Grand Rapids: Zondervan Publishing House.

Garland, D. (2002). Mark. In: Zondervan Illustrated Bible backgrounds commentary: Volume 1. Grand Rapids: Zondervan Publishing House.

Hargreaves, J. (1995). A guard to St. Mark's Gospel. Cambridge: SPCK.

Henry, M. (1961). New one volume edition commentary on the whole bible. Grand Rapids: Zondervan Publishing House.

House, R. J., \& Mitchell, T. R. (1974). Path-goal theory of leadership. Journal of Contemporary Business 3, 81-97.
Kraybill, D. B. (2018). The upside-down kingdom. Harrisonburg: Herald Press.

Lewin, K., Lippitt, K., \& White, R. K. (1939). Patterns of aggressive behavior in experimentally created 'Social Climates'. Journal of Social Psychology, 10(2), 269-299.

Malbon, E. S. (2006). The significance of Jesus' death in Mark: Narrative context and authoritative audience. Journal of Biblical Literature, 125, 271-279.

Metzger, B. M. (1994). Textual commentary of the Greek New Testament. U.S.A: United Bible Society Publishers.

Robertson, A. I. (2018). Lessons on the gospel of Saint Mark. Classic Reprint. London: Forgotten Books.

Scroggie, W. G. (1980). The gospel of Mark. Grand Rapids: Zondervan Publishing House.

Sewakpo, H. M. (2015). An African's Perspective on Leadership in the Book of Titus. Ilorin Journal of Religious Studies, 5(2), 1 22.

Wallace, D. B. (1996). Greek grammar beyond the basics. Grand Rapids: Zondervan Publishing House.

Wiersbe, W. W. (1989). The bible exposition commentary. USA: C.V. Publishing.

Weitnauer, R. (2015). The Making of a Leader by Robert Clinton - A Book Review. Reasons for God. Retrieved 21 December 2020 from https://reasonsforgod.org/the-making-of-a-leaderby-robert-clinton-a-book-review/.

Wilkes, C. G. (1998). Jesus on leadership: Illinois: Tyndale House. 